$\begin{array}{llr}\text { KULTURA } & \begin{array}{l}\text { POLSKA A KADEMIA NAUK } \\ \text { KOMITET SOCJOLOGII }\end{array} & \begin{array}{r}\text { ISSN 0023-5172 } \\ 2300-195 x\end{array} \\ \text { i } & \begin{array}{l}\text { INSTYTUT STUDIÓW POLITYCZNYCH } \\ \text { SPOLECZENSTMO }\end{array} & \\ 2020, \text { nr 2 ANTROPOLOGIA ZAANGAŻOWANA } & \end{array}$
$\begin{array}{llllllll}A & R & T & Y & K & U & £ & Y\end{array}$
I
$\begin{array}{llllllll}\mathrm{R} & \mathrm{O} & \mathrm{Z} & \mathrm{P} & \mathrm{R} & \mathrm{A} & \mathrm{W} & \mathrm{Y}\end{array}$

ANNA KURPIEL

Centrum Studiów Niemieckich i Europejskich im. Willy Brandta, Uniwersytet Wroctawski

KATARZYNA MANIAK

Instytut Etnologii i Antropologii Kulturowej Uniwersytetu Jagiellońskiego

\title{
CERAMIKA Z BOLESŁAWCA — DZIEDZICTWO W TRANZYCIE*
}

$\mathrm{Na}$ bolesławieckiej ceramice podano posiłek papieżowi Janowi Pawłowi II na pokładzie Polskich Linii Lotniczych LOT, gdy odwiedził Polskę w 1997 roku. Serwis z Bolesławca został wręczony brytyjskiej parze książęcej przez prezydenta Andrzeja Dudę w 2017 roku. Rok później amerykańska Centralna Agencja Wywiadowcza zamówiła zastawę stołową z bolesławieckiej ceramiki ozdobioną jej logotypem. Wyroby z Bolesławca można kupić na polskich lotniskach jako gifts from Poland, a także w większych polskich miastach i regionach turystycznych, takich jak Mazury czy Podhale. Można je spotkać na stołach w polskich gospodarstwach agroturystycznych, pojawiają się na zdjęciach promujących je „influencerów” oraz na planach popularnych seriali, a także w mediach społecznościowych grup zrzeszających entuzjastów bolesławieckich wyrobów ${ }^{1}$. Krótko mówiąc, ceramika z Bolesławca wydaje się znana, powszechnie rozpozna-

Adres do korespondencji: anna.kurpiel@uwr.edu.pl; ORCID: 0000-0001-8919-4347; katarzyna.maniak@uj.edu.pl; ORCID: 0000-0001-5498-4621

* Artykuł powstał w ramach projektu „Rzeczy(wistości) w przestrzeni postkonfliktu. Znaczenia przedmiotów w tworzeniu się światów wyobrażonych Wrocławia i Szczecina" finansowanego ze środków Narodowego Centrum Nauki przyznanych na podstawie decyzji numer DEC-2018/31/D/HS3/00778.

${ }^{1}$ Między innymi Grupa Zakłady Ceramiczne „BOLESŁAWIEC” oraz Ceramika z Bolesławca - I love it! 
walna, swojska, a nawet więcej — jak pokazują wspomniane przykłady — jest przedmiotem reprezentatywnym, traktowanym jako symbol Polski. Nasze badanie zainicjowało proste pytanie - jak to możliwe, skoro jeszcze kilkadziesiąt lat temu ceramika $z$ Bolesławca była ceramiką z Bunzlau, wyrabianą od stuleci przez niemieckich rzemieślników?

Bolesławiec to miasto leżące na tzw. Ziemiach Zachodnich i Północnych przyłączonych do Polski po drugiej wojnie światowej. Podobnie jak w innych dolnośląskich miastach $\mathrm{w}$ wyniku powojennego przesunięcia granic nastąpiła w nim niemal całkowita wymiana ludności. Przedwojenni mieszkańcy zostali wysiedleni do Niemiec, a na ich miejsce przybyli osadnicy z całej Polski, przymusowi przesiedleńcy zza Buga, a także reemigranci z Francji, Belgii i Jugosławii. Ziemie Zachodnie - w oficjalnej propagandzie „odzyskane” i „przywrócone Macierzy” — po wojnie stały się wielkim społecznym laboratorium, w którym spotkały i mieszały się elementy odmiennych kultur, tradycji, zwyczajów i religii. Podstawowe dyrektywy powojennej władzy dla nowo przyłączonych obszarów dotyczyły ich homogenizacji kulturowej, integracji z resztą kraju oraz „repolonizacji” i „degermanizacji” ${ }^{2}$. Koniec tej odgórnie kreowanej polityki nastąpił wraz z transformacją ustrojową, co otworzyło pole nowym, lokalnym narracjom, bazującym na heterogenicznym dziedzictwie kulturowym regionu. W latach dziewięćdziesiątych XX wieku Dolny Śląsk oraz poszczególne jego miasta, chcące odciąć się od PRL-owskiej propagandy, zaczęły „wymyślać się” na nowo, szukając dla siebie tożsamościowej dominanty, w tym - produktu regionalnego.

Kinga Siewior (2019, s. 93-94) pisze: „dyskurs Ziem Odzyskanych mimowolnie wytracał swój tożsamościowy potencjał, przekształcając się w narzędzie natrętnej propagandy”. Jej zdaniem, powojenna narracja o przestrzeniach włączonych $\mathrm{w}$ granice Polski uniemożliwiła społeczne przepracowanie postkonfliktowych migracji, co sprawiło, że przestrzenie te „funkcjonują [dziś] nie jako miejsca pamięci zakładające istnienie jakiejś wspólnoty czy jedność kulturową, lecz raczej jako negatywny mnemotopos, przypominający zaledwie o pewnym (niewygodnym) fragmencie przeszłości konkretnych obszarów geograficzno-kulturowych, który ich tożsamość de facto dławił". Przedstawiona tu analiza stanowi próbę wypełnienia luki dostrzeżonej przez badaczkę i jest motywowana chęcią ukazania nieraz zaskakujących trajektorii szlaków migracyjnych ukrytych w przedmiotach ${ }^{3}$.

\footnotetext{
2 Propagandowa dyrektywa „repolonizacji” w istocie oznaczała polonizację nowo przyłączonych obszarów (zob. Thum 2007).

${ }^{3}$ Jest to analiza fenomenu na poziomie społecznym, z powodu limitów narzuconych przez rozmiar tekstu pomijamy recepcję tej formy dziedzictwa kulturowego w perspektywie indywidualnej.
} 
Wzmianki o historii ceramiki bolesławieckiej można znaleźć jedynie w kilku publikacjach naukowych dotyczących Dolnego Śląska (Baniecki 2006; Demshuk 2012, s. 73-74), w monografiach poszczególnych zakładów (Żak 2007; Górecki 2000), polskich i niemieckich wydawnictwach muzealnych (Starzewska, Wolanin 1995; Bober-Tubaj, Moniatowicz 2014; Spindler 2004; Schöne 2004) oraz w dokumentach Cechu Ceramików Bolesławieckich. Dostępne opracowania pomijają jednak najbardziej interesujące nas kwestie, powojenne losy wzorów o niemieckiej proweniencji. Śladów biografii ceramiki szukałyśmy w dostępnej literaturze, lokalnej prasie "na gorąco" raportującej stan regionalnego dziedzictwa, a także $\mathrm{w}$ rozmowach $\mathrm{z}$ osobami zaangażowanymi $\mathrm{w}$ badania historii przemysłu ceramicznego 4 .

Bolesławieckie wyroby z jednej strony uważane są za "odwieczne” (pierwsze pochodzą z okresu średniowiecza), z drugiej są modne obecnie. Pomiędzy dalekim wtedy a dziejącym się teraz istnieje świadomościowa luka, fenomen ceramiki stempelkowej silnie kształtuje jej bardziej wyobrażony niż rzeczywisty obraz z przeszłości.

\section{POWOJENNA HISTORIA CERAMIKI — PRÓBA REKONSTRUKCJI}

W lipcu 1945 roku do opuszczonych ${ }^{5}$ bolesławieckich fabryk przybył Tadeusz Szafran, artysta ceramik, wykształcony zarówno w krakowskiej Akademii Sztuk Pięknych, jak i w niemieckiej Wyższej Szkole Ceramicznej w Höhr koło Koblencji. Doświadczenie zdobywał między innymi kierując wydziałem ceramicznym w Królewskiej Szkole Przemysłu Artystycznego w Weimarze i pracownią ceramiki w Szkole Sztuk Zdobniczych i Przemysłu Artystycznego w Krakowie (Rejwerska 2011). Do Bolesławca trafił jako rzeczoznawca przemysłu ceramicznego Dolnośląskiej Grupy Operacyjnej, której zadaniem była ocena i inwentaryzacja zakładów przemysłowych na ziemiach włączonych w granice Polski. Specjalistyczne wykształcenie oraz znajomość języka niemieckiego umożliwiły mu pracę nad wznowieniem działalności zakładów. To właśnie Szafran wraz ze współpracownikami był odpowiedzialny za opracowanie odpowiednich procedur i receptur cera-

\footnotetext{
${ }^{4}$ Szczególnie podziękowania kierujemy do Pani Anny Bober-Tubaj, dyrektorki Muzeum Ceramiki w Bolesławcu.

${ }^{5}$ Warto dodać, iż dla pierwszych miesięcy i lat powojennych charakterystyczna była niepewność co do przesiedleń ludności. Na terenach Bolesławca jeszcze przez kilka lat po zakończeniu wojny wciąż pozostawali Niemcy wierzący w możliwość dalszego życia w dawnej ojczyźnie. Wśród powodów opóźnienia ich wysiedleń istotną rolę odgrywała chęć pozyskania wiedzy o przejmowanych zakładach przemysłowych (zob. Baniecki 2006).
} 
micznej sztuki i zorganizowanie na nowo bolesławieckiego przemysłu. Tytaniczny charakter prac sygnalizują opisy zastanego przez nich krajobrazu. „Jechałem do Legnicy - relacjonował Szafran — bez mała tydzień wagonem dla bydła, łatwo możecie sobie wyobrazić. W Legnicy byłem dwa dni i autem dojechałem do Bolesławca. Tutaj Śląsk jest bardzo piękny. Bolesławiec byłby śliczny, gdyby nie zniszczenia. [...] Dla ceramika jest tu, względnie będzie raj prawdziwy. Są tu małe warsztaty, duże i olbrzymie fabryki, wszystko unieruchomione, częściowo popalone, maszyny wymontowane i wywiezione" (cyt. za: Rejwerska 2011, s. 8).

Obraz dewastacji dokonanych przez Armię Radziecką oraz grupy szabrowników wzmacnia wypowiedź ówczesnego technika-ceramika:

„Zakład Paula (mieścił się przy obecnej ul. Polnej 19) podczas mego pobytu w Bolesławcu w 1943 r. był jednym z najnowocześniej urządzonych. Wiosną 1946 roku, oprócz $2 \mathrm{~kg}$ gąbek rozrzuconych dosłownie po wszystkich kątach fabryki, nie zastałem tam nic więcej” (cyt. za: Rejwerska 2011, s. 8).

Pierwszy uruchomiony zakład należał przed wojną do Richarda Reinholda i mieścił się przy ulicy Górne Młyny. Znaczącą rolę odegrała jednak wspomniana fabryka Juliusa Paula, najlepiej prosperująca w okresie przedwojennym ${ }^{6}$, która w 1949 roku została zaanektowana przez Robotniczą Spółdzielnię Wytwórczą Ceramiki i Robót Instalacyjno-Budowlanych. W kolejnym roku, zgodnie $z$ decyzją Państwowej Komisji Planowania Gospodarczego, zakład przeszedł pod zarząd wrocławskiego oddziału Centrali Przemysłu Ludowego i Artystycznego (popularnie zwanej Cepelią). Nowo założona Spółdzielnia miała zająć się ceramiką ozdobną i wyrobami artystycznymi i z powodu braków kadrowych, a przede wszystkim zgodnie $z$ linią programową Cepelii, zainicjowała współpracę z Państwową Wyższą Szkołą Sztuk Plastycznych we Wrocławiu. Artystyczną opiekę nad działalnością Spółdzielni objęli kolejno Mieczysław Pawełko, Julia Kotarbińska i Rudolf Krzywiec, absolwenci warszawskiej Akademii Sztuk Pięknych, związani ze spółdzielnią „ŁAD”.

Wytwarzane wyroby szybko włączono w ofertę sprzedażową Cepelii. W pierwszych latach korzystano z niemieckich form, gdyż najważniejsze było ponowne uruchomienie produkcji, co na krótki moment przyćmiło kwestie ideologiczne. Stopniowo jednak opracowywano nowe kształty. Natomiast wzornictwo zostało zmienione niemal natychmiast, projektanci sięgali zwłaszcza do repertuaru polskiej sztuki ludowej (Żak 2007, s. 9).

${ }^{6}$ Między innymi dzięki współpracy z Ceramiczną Szkołą Zawodową otwartą w mieście w 1897 roku (zob. Żak 2007, s. 4). 
Zwrot ten wynika z kilku czynników. Po pierwsze, przybyli na Dolny Śląsk artyści i ceramicy projektowali w duchu szkół, z których się wywodzili, przeważnie krakowskiej lub warszawskiej, a ambicje zawodowe kierowały ich w stronę poszukiwań unikatowych wzorów (tj. malatury, nacieki, sgraffito). Po drugie, istotną rolę odegrała powszechna niechęć, a nawet wrogość do niemieckiej spuścizny, podsycana przez oficjalną propagandę ${ }^{7}$. Według jednego z producentów ceramiki: „wszystko, co niemieckie, było niedobre. To trzeba było zniszczyć, zrobić od nowa, zrobić po polsku i wtedy będzie to dobre. No taka była mentalność przez długi okres czasu" ${ }^{8}$.

Wspomniane na wstępie dyrektywy polonizacji i degermanizacji dotyczyły również produkcji ceramiki, która jak najszybciej musiała zostać włączona w ramy polskiej kultury. Wpływ instytucjonalnego dyskursu na stosunek Polaków do poniemieckiego dziedzictwa doskonale opisuje Agata Zborowska. Badaczka wskazuje na rolę dekretu o „majątkach porzuconych i opuszczonych" z marca 1945 roku i dokonane za jego pomocą "powołanie do życia przedmiotów opuszczonych i porzuconych", co wystarcza, „by je uwolnić, w społecznej wyobraźni przestają bowiem funkcjonować jako podwiązane do podmiotów, ich prawnych właścicieli" (Zborowska 2019, s. 86). Stają się tym samym niczyje, a więc czekające na przejęcie. Zborowska wskazuje również inne mechanizmy zawłaszczania $^{9}$, mające odzwierciedlenie $\mathrm{w}$ na poziomie lingwistycznym, na przykład przez określanie niemieckiego mienia jako „majątku nieprzyjacielskiego" (Zborowska 2019, s. 124). Autorka opisuje także działalność Biura Nadzoru Estetyki Produkcji, którego celem było zwalczanie oznak przedwojennej rzeczywistości (takich jak wzornictwo) reprodukowanych w zakładach przemysłowych tzw. Ziem Odzyskanych. Ślady nieakceptowanej przeszłości zostają więc „przeniesione do sfery niechcianego dziedzictwa” (Zborowska 2019, s. 264), wyeliminowane lub poddane radykalnej modyfikacji,

7 Warto dodać, że ceramika pozostawiona przez Niemców niejednokrotnie okazywała się przydatna $\mathrm{w}$ czasach powojennego niedostatku. Tym samym znajdowała się $\mathrm{w}$ wielu gospodarstwach domowych powiatu bolesławieckiego.

${ }^{8}$ Wywiad z J.R. (4 lipca 2019, Tomaszów Bolesławiecki).

${ }_{9}^{9} \mathrm{~W}$ wielu analizach powojennej rzeczywistości tzw. Ziem Odzyskanych, wykorzystywano pojęcie „oswojenia” jako celnie opisujące praktyki zasiedlenia przyłączonych terenów. Może być ono pomocne na przykład w opisie indywidualnych praktyk i zachowań osób przesiedlonych z Kresów, jeszcze przez długi czas wierzących w powrót do swoich lokalnych ojczyzn. Jednak na poziomie analiz oficjalnego dyskursu trafniejsze wydaje się stosowanie precyzyjnego języka wskazującego na procesy polonizacji, kolonizacji, przejęcia czy zawłaszczenia. W naszym przekonaniu ta terminologia oddaje charakter mechanizmów włączenia Dolnego Śląska w granice Polski, obejmuje bowiem nacisk na przymusowe i nieraz przemocowe wysiedlenia, przejęcie mienia, praktykę szabru i wymazywania historii regionu. 
w efekcie której konotują odmienne porządki. Doskonałym przykładem takiej paradoksalnej kombinacji postaw odrzucania i przejęcia jest casus niemieckich stempelków omówiony w dalszej części tekstu.

W 1951 roku bolesławiecka Spółdzielnia zakończyła współpracę z Państwową Wyższą Szkołą Sztuk Plastycznych we Wrocławiu, zadanie kontrolowania jakości artystycznej produkcji cedując na funkcję kierownika artystycznego, którą na początek powierzono Izabeli Zdrzałce. Absolwentka wspomnianej PWSSP we Wrocławiu, pełniąca tę rolę w latach 1951-1957, wyraźnie zapisała się na kartach historii zakładu jako prekursorka nowych form i wyjątkowych propozycji zdobień. Jej projekty „charakteryzowała różnorodność kształtów i dekoracji, z malaturami różkiem, stosowaniem wielobarwnych szkliw oraz pracochłonną techniką rytu, które do dziś stanowią interesujący przykład połączenia sztuki ludowej z nowoczesną formą naczyń" (Żak 2007, s. 9).

W pierwszych latach ramy działania Spółdzielni „Ceramika Artystyczna” określała ideologia propagowana przez ugruntowujące się struktury komunistycznej władzy. Jej najbardziej jaskrawy przykład, dotyczący narzędzi zawłaszczenia i polonizacji ceramiki, opisałyśmy wyżej. Co więcej, zakłady ceramiczne zaprezentowano na „Wystawie Ziem Odzyskanych" (1948) ${ }^{10}$, czyli ekspozycji o propagandowym charakterze, której celem było wzmocnienie mitu Ziem Odzyskanych dla Macierzy i ukazanie osiągnięć trzyletniego programu odbudowy. Tym samym ceramikę włączono, po raz pierwszy w sposób instytucjonalny, w imaginarium polskiej rzeczy (wistości), nadając jej status jednej z gałęzi przemysłu stanowiącego bazę rozwoju gospodarczego kraju. Podobnie objęcie zakładów strukturalnym patronatem Cepelii, produkującej polską „ludowość na sprzedaż” (Korduba 2013), wpisuje ceramikę bolesławiecką w ramy krajowej wytwórczości. Wskazuje również na jeszcze inne wymiary instrumentalizacji, tym razem związanej z ludowością (Kordjak 2016, s. 11-39). Ważną linią programową Cepelii była organizacja współpracy twórców „ludowych” $\mathrm{z}$ artystami, którą kontynuowano $\mathrm{w}$ formule plenerów ceramicznych, organizowanych w Bolesławcu od lat sześćdziesiątych XX wieku. Ponadto warto podkreślić rolę kolejnego narzędzia legitymizującego status analizowanych przedmiotów, czyli instytucji muzeum. Wyroby Spółdzielni, zwłaszcza te autorstwa Izabeli Zdrzałki, już od lat pięćdziesiątych pokazywano

10 Zjednoczone Zakłady Garncarsko-Ceramiczne mieszczące się przy ul. Górnych Młynów 10 (dawne zakłady Reindolda) były prezentowane w Dziale B wystawy, wśród innych wystawców sektora państwowego (zob. Katalog oficjalny wystawy ziem odzyskanych 1948, s. 154). 
w ówczesnym Muzeum Śląskim (obecnie Narodowym) we Wrocławiu, co miało uprawomocnić ich pozycję na polu kultury i sztuki. W 1967 roku utworzono Muzeum Ceramiki w Bolesławcu, którego zbiory były systematycznie zasilane wyrobami z pobliskiego zakładu.

Co ciekawe, aspiracje artystyczne ceramików oraz charakter produkcji sprawiły, że w Polsce Ludowej ceramika bolesławiecka należała raczej do produktów luksusowych $-z$ wyłączeniem jednokolorowej kamionki użytkowej i wyrobów eksportowych. Tym samym poza regionem Bolesławca, który obfitował zarówno w ceramikę przedwojenną, jak i powojenną, nie stanowiła elementu rozpoznawalnego, $w$ przeciwieństwie do popularnych wówczas wyrobów z Włocławka.

Kolejny istotny moment $\mathrm{w}$ historii ceramiki związany jest $\mathrm{z}$ postacią Bolesława Wolanina, odpowiedzialnego za kierownictwo artystyczne Spółdzielni od 1964 roku, męża wieloletniej dyrektorki Muzeum Ceramiki. To on bowiem, podobnie jak Irena Zdrzałka, tworzył szczególnie doceniane i nagradzane wzornictwo i, co istotne, przywrócił do łask przedwojenne stempelki. Początkowo szukał inspiracji w twórczości ludowej, jednak w latach siedemdziesiątych sięgnął do tradycji niemieckich i zdobień motywami stempelkowymi, które z czasem zdominowały projektowane przez niego formy.

„Właśnie ten rodzaj dekoracji — twierdzi Katarzyna Żak (2007, s. 11) — wywodzący się jeszcze z XIX-wiecznej tradycji, a doprowadzony do perfekcji w wyrobach firmy Juliusa Paula — powróci w mistrzowskiej wersji Bronisława Wolanina. Jednak renesans stempelków; nie oznacza ich wiernego naśladownictwa. Inwencja artysty, wsparta możliwościami technicznymi całego zespołu pracowników, w tym technologów i malarek, zaowocuje świeżym i oryginalnym potraktowaniem spuścizny".

\section{BOLESŁAWIECKIE STEMPELKI — DZIEDZICTWO WIELU DZIEDZICÓW}

Warto podkreślić, iż dokonany wówczas transfer stempelkowej metody zdobniczej nie polegał na pokonaniu dystansu historycznego, miał raczej wymiar przestrzenny. Ceramika dekorowana wycinanymi z gąbki stempelkami, choć powstała w Bolesławcu około 1882 roku, bardzo szybko stała się popularna w całych przedwojennych Niemczech. Na początku $\mathrm{XX}$ wieku wyroby stołowe zdobione stempelkami zaczęły być wytwarzane przez kilka znaczących firm, między innymi berlińską Petersena lub Villeroy\&Boch, działającą do dzisiaj. Lata 1910-1914 stały się złotym okresem ceramiki stempelkowej, którą dla uproszczenia zaczęto nazywanać bunzlauer keramik — od prekursorskich bolesławieckich zakładów. 
Żaden inny wzór nie był tak bardzo kojarzony z bolesławieckim przedwojennym ośrodkiem ceramicznym, a tym samym z niemieckim dziedzictwem kulturowym ${ }^{11}$. Fakt ten w oczywisty sposób wykluczał kobaltowe stempelki z powojennej krajowej produkcji na masową skalę. Jeśli pojawiały się na powojennych naczyniach, to jedynie sporadycznie jako element indywidualnych poszukiwań artystycznych ${ }^{12}$. Jednak zaniechanie produkcji stempelków w powojennym, już polskim Bolesławcu nie wiązało się $z$ ich zanikiem. Metoda stempelkowa była kontynuowana przez niemieckich ceramików, którzy po wojnie zostali przesiedleni do NRD ${ }^{13}$. W swoich nowych miejscach zamieszkania, przede wszystkim na terenie Saksonii i Łużyc, otwierali rodzinne warsztaty, w których kontynuowali ceramiczne tradycje, także stempelkowe.

W RFN pamięć o opuszczonej ojczyźnie mogła być kultywowana i afirmowana. Zakładano więc ziomkostwa oraz izby pamięci, tak jak w przypadku Niemców z Bolesławca, którzy trafili do Siegburga w Niemczech Zachodnich i w latach siedemdziesiątych XX wieku utworzyli Bundesheimatgruppe Bunzlau zu Siegburg - stowarzyszenie byłych mieszkańców Bolesławca oraz izbę regionalną, w której prezentowano dużą kolekcję bolesławieckiej ceramiki ${ }^{14}$. Stempelki stały się dla nich elementem materializującym nostalgię i pamięć za opuszczonym miastem, a bunzlauer keramik nadal była znana i produkowana, choć na mniejszą skalę, w całych Niemczech. Jak zauważył pracownik Muzeum Śląskiego w Görlitz:

${ }^{11}$ Inny rodzaj ceramiki kojarzonej z niemieckim obszarem kulturowym to tzw. buncloki, czyli ceramika szkliwiona jednobarwna - najczęściej brązowa lub piaskowa. Jej losy są jednak odmienne od tej dekorowanej stempelkami, gdyż była produkowana na większą skalę przez powojenne zakłady bolesławieckie i stała się jednym z najlepiej rozpoznawalnych towarów na rynku.

12 Jeśli chodzi o eksponaty zdobione metodą stempelkową, to w Muzeum Ceramiki znajduje się serwis do kawy z lat pięćdziesiątych autorstwa Krystyny Cybińskiej (Zakłady CPLiA), naczynia - forma autorstwa Amandy Różańskiej (autor dekoracji niewymieniony, CPLiA, lata pięćdziesiąte). Kolejne eksponaty zdobione stempelkami, autorstwa Wolanina, pochodzą już z lat dziewięćdziesiątych XX wieku).

${ }^{13} \mathrm{~W}$ wyniku powojennego przesunięcia granicy bolesławieccy ceramicy zostali zmuszeni do opuszczenia miasta. Nie stało się to jednak natychmiastowo. Byli bowiem - podobnie jak inni niemieccy rzemieślnicy - cennym źródłem informacji dla Polaków przybyłych na obce kulturowo i zniszczone Ziemie Zachodnie. Stosunkowo późne wysiedlenie ich z Polski spowodowało, że trafili do NRD, nie zaś, jak pierwsi przesiedleńcy, do RFN.

${ }^{14}$ W 2019 roku kolekcja z Siegburga została przekazana do Muzeum Ceramiki w Bolesławcu. Przedwojenna ceramika, pokazywana od sierpnia 2019 roku na wystawie czasowej o wiele znaczącym tytule „Przyjaciele dla nowego muzeum”, po latach powróciła w ten sposób do swojej „ojczyzny” - zarówno fizycznie, jak i symbolicznie, na znak polsko-niemieckiej współpracy na polu trudnego dziedzictwa. 
„Bolesławiecka ceramika odgrywa ważną rolę we wspomnieniach wielu Ślązaków pochodzenia niemieckiego. Dla wielu $z$ nich jest kawałkiem «małej ojczyzny». Bardzo wielu z nich z upływem czasu zebrało małą kolekcję. Wśród przedmiotów pamiątkowych [...] zawsze była ceramika bolesławiecka" ${ }^{15}$.

Na początku lat osiemdziesiątych w Bolesławcu istniały zakłady specjalizujące się w ceramice stołowej lub użytkowej, w tym kilka prywatnych ${ }^{16}$, a za zamkniętą granicą między sąsiadującymi państwami szereg małych rodzinnych manufaktur niegdysiejszych bunzlauerów. Sytuacja wkrótce zaczęła się dynamicznie zmieniać, przede wszystkim wraz z sukcesywnym rozwojem kontaktów handlowych między Polską a Zachodem, z Republiką Federalnych Niemiec na czele. Kulminacyjnym momentem zmian, a zarazem początkiem nowej historii $\mathrm{w}$ dziejach ceramiki, była polska transformacja ustrojowa.

Lata dziewięćdziesiąte to burzliwy okres w dziejach bolesławieckiej ceramiki. Początek kapitalizmu, koniec gospodarki planowanej centralnie, otwarcie na inne rynki zbytu poza krajami bloku wschodniego - wszystko to spowodowało zmiany w polityce bolesławieckich firm, a także umożliwiło rozwój nowych, prywatnych przedsiębiorstw. Zakłady, które dotychczas produkowały jednobarwną kamionkę lub - jak państwowe zakłady Ceramika Bolesławiec - ceramikę użytkową: muszle klozetowe, umywalki czy rury, zaczęły się specjalizować w dekorowanej ceramice stołowej. Co więcej, wspomniana już nostalgia za przedwojennym bolesławieckim dziedzictwem odczuwana w Niemczech w powiązaniu z procesami, które zaczęły zachodzić w Polsce, a więc powrotem Bronisława Wolanina do stempelków, zaowocowały nagłym zwrotem w historii omawianej przez nas ceramiki. Pod koniec lat osiemdziesiątych do Bolesławca przyjechała Polka, Irena Heise, wraz ze swoim niemieckim mężem Rudolfem Heise, by przedstawić polskim ceramikom intratną, w początkowym odczuciu, współpracę biznesową. Zaoferowali oni wznowienie produkcji z wykorzystaniem przedwojennych form i wzorów, a także techniki ręcznego stempelkowania według przywiezionych przez nich wzorników. Całość polskiej produkcji miała być sprzedawana na rynek niemiecki, za pośrednictwem firmy Heise, po wysokich jak na ówczesne standardy cenach.

\footnotetext{
15 Film „Ceramika Bolesławiecka z Wytwórni Reinholda” (https://vimeo.com/5389849 [dostęp: 29.10.2019]).

${ }_{16}$ Pierwszy zakład prywatny - Ceramika Artystyczna „Wiza” powstał w 1963 roku, kolejne: Przedsiębiorstwo Produkcyjno-Handlowe „Rutpol” oraz Wykonywanie Ceramiki Zdobnej „Ada” w latach siedemdziątych.
} 
Początkowo produkcją ceramiki stempelkowej wzorowanej na przedwojennej zajęła się Spółdzielnia Ceramika Artystyczna w Bolesławcu oraz jeden z prywatnych zakładów. Jednak współpraca z niemieckim wspólnikiem układała się nie najlepiej i zakończyła otwartym sporem sądowym, który poróżnił zarówno polsko-niemieckie, jak i lokalne środowisko. Konflikt rozpoczęty za sprawą firmy Heise przebiegał na dwóch płaszczyznach, co istotne również $\mathrm{w}$ naszych rozważaniach. Pierwsza dotyczyła zagadnienia dziedzictwa i pytania o to, kto jest spadkobiercą „autentycznej” ceramiki stempelkowej i zarazem ma do niej prawa. Kilku polskich oraz niemieckich ceramików uznawało siebie za współczesnych „odkrywców”, kontynuatorów lub (re)interpetatorów przedwojennego zdobnictwa niemieckiego, a tym samym za jedynych dysponentów prawa do wzoru. $\mathrm{Z}$ zagadnieniem dziedzictwa i patentu zazębiała się kolejna płaszczyzna sporu - sfera ekonomiczna. Prawa własności wiązały się bowiem z prawem do produkcji. Masowa produkcja stempelkowej ceramiki przez lokalne niemieckie manufaktury została uznana za zagrożenie. Małe rodzinne zakłady przestały być konkurencyjne w obliczu polskich przedsiębiorstw, rozbudowywanych od dziesięcioleci lub masowo powstających po transformacji ustrojowej. Spór sądowy zakończył się „uwolnieniem” najstarszych zdobień stempelkowych (w tym tzw. pawich oczek), które są dostępne na wolnej licencji i mogą być produkowane przez wszystkie zakłady.

Opisane spory kierują nas ku rozważaniom o charakterze badanego dziedzictwa kulturowego. Jednym z terminów nasuwających się w odniesieniu do spuścizny po wysiedlonych Niemcach jest określenie „dziedzictwo osierocone" (orphaned heritage), zaproponowane przez brytyjskiego archeologa Jona Price'a (2005). O osieroconym dziedzictwie mówimy, gdy znajduje się ono w oddaleniu od swoich (prawowitych) dziedziców. Przez nowych właścicieli może być niszczone, zagrabione lub też docenione i włączone $\mathrm{w}$ proces tworzenia się nowego lokalnego dziedzictwa. Wszystkie te procesy miały miejsce w przypadku ceramiki bolesławieckiej, która po wojnie była niszczona (zarówno przez Armię Czerwoną, jak i polskich osadników), przejęta (w wyniku szabru, kradzieży oraz polonizacji fabryk), a także - szczególnie w ostatnich dekadach - doceniona.

Polska badaczka Roma Sendyka wzbogaciła termin Price'a zarówno o polską specyfikę, jak i wymiar moralny. Skupiła się na badaniu wojennego i powojennego mienia żydowskiego i zaproponowała termin „kaduczne dziedzictwo" (escheated/caducary heritage), wykorzystując koncepcję własności wywodzącą się z prawa rzymskiego (Sendyka 2018). Tak skonceptualizowane dziedzictwo jest nie tylko opuszczone przez właścicieli, po których pozostaje pustka. Zaproponowany przez Sendykę termin od- 
nosi się również do relacji z pozostawionym dziedzictwem materialnym, którego przejęcie przez nowych właścicieli zawiera element brutalności, konfliktu czy naruszenia zasad moralnych. Uruchamia tym samym nowe łańcuchy powiązań - między innymi zawiera nawiązania do koncepcji dziedzictwa (post)konfliktowego.

Przypadek ceramiki bolesławieckiej skłania nas jednak do dalszych poszukiwań terminologicznych. Linearny rozwój akcji: opuszczenie zawłaszczenie - docenienie, w przypadku ceramiki bolesławieckiej jest o wiele bardziej skomplikowany. Po pierwsze, następuje tu nałożenie dwóch porządków: dziedzictwa materialnego (fabryki czy dobrej jakości bolesławiecka glina, niezbędna do powstania surowca), które zostało opuszczone, osierocone $\mathrm{w}$ Polsce, oraz dziedzictwa niematerialnego (umiejętność wyrobu ceramiki stempelkowej), które w oderwaniu od ojczyzny było kontynuowane po wojnie przez prawowitych „dziedziców”. Po drugie, wiele przeciwstawnych procesów następowało jednocześnie. Tuż po wojnie, gdy szabrownicy i nowi osadnicy niszczyli maszyny i ocalałą ceramikę, Tadeusz Szafran wraz z niemieckimi ceramikami uruchamiał pierwszą fabrykę. Początek XXI wieku cechuje natomiast $z$ jednej strony spór o prawa autorskie, $z$ drugiej owocna współpraca polsko-niemiecka, łącząca między innymi byłych mieszkańców Bunzlau osiedlonych w Siegburgu i współczesnych bolesławian pracujących w lokalnym muzeum.

Dlatego też chciałybyśmy zaproponować kolejny termin, który w naszym odczuciu oddaje specyfikę analizowanego fenomenu. Ceramika bolesławiecka i praktyka jej wyrobu - częściowo opuszczona, ale nie zaniechana, przyciągająca nowe kręgi spadkobierców, rodząca konflikty, ale i stanowiąca łącznik pomiędzy dziedzicami - wydaje się raczej dzie dzictwem wielu dziedziców niż dziedzictwem osieroconym. Za pomocą tego terminu chcemy opisać wielość osób i instytucji oraz strategii i afektów (nieraz sprzecznych i pozostających w konflikcie), które składają się na dzisiejszy kształt tego dziedzictwa.

\section{WSPÓŁCZESNY OBRAZ CERAMIKI}

Przełom wieków w historii ceramiki charakteryzuje otwarcie na nowe rynki zbytu, co po raz kolejny ujawnia splot rozmaitych czynników kształtujących jej formy i znaczenia. Większość wyrobów państwowej firmy Ceramika Artystyczna, a także prywatnych przedsiębiorstw, produkowana była $\mathrm{w}$ tym okresie z przeznaczeniem na eksport. Jak podają lokalne źródła, stempelkowana ceramika podobała się nie tylko w Niemczech, ale i we Francji, Włoszech i Stanach Zjednoczonych, do których trafiła, gdy pod- 
patrzyły ją partnerki odwiedzające żołnierzy stacjonujących w niemieckich bazach NATO ${ }^{17}$. Firmy zaangażowały się w działalność promocyjną, dzięki której na ekranach amerykańskich telewizorów na telezakupowym kanale QVC wyświetlały się wyroby ceramiczne ${ }^{18}$, oraz we współpracę $z$ amerykańskimi sieciami handlowymi, takimi jak T.K. Maxx, HomeGoods, Cost Plus. Do amerykańskiego klienta dostosowano zdobienia naczyń, preferowane bowiem były duże wzory, najchętniej kwiatowe, w niebieskiej oraz czerwonej tonacji. Dziś na stronach platformy ebay pod hasłem boleslawiec pottery można znaleźć wielorakie i nieraz fantazyjne wyroby, często w wersji „patriotycznej” z motywem flagi Stanów Zjednoczonych.

Jednak zbyt towarów na rynek Stanów Zjednoczonych gwałtownie ograniczyła działalność chińskich przedsiębiorców, którzy podrabiali bolesławiecką ceramikę. Duże znaczenie miał także spadek wartości dolara zmniejszający rentowność sprzedaży za ocean. Polskie firmy otwarły się więc na nowe, tym razem wschodnie rynki (Japonia, Korea Południowa, Chiny, Tajwan) ${ }^{19}$. Wymianę handlową ułatwiła umowa podpisana w 2011 roku między Unią Europejską a Koreą Południową, skąd towary trafiały do kolejnych odbiorów. Ceramika kolejny raz ujawniła swoją plastyczność, wychodząc naprzeciw oczekiwaniom nowych użytkowników. Jak podaje prezes Manufaktury Bolesławiec: „W Azji podobają się barwy bardziej intensywne i weselsze, takie jak pomarańcz, turkus czy mięta" ${ }^{20}$, popularnością cieszą się również wzory kwiatowe. W Japonii z kolei wybierano „tonację głęboką - kobalt i skromny motyw białych kropek”. Wprowadzono też modyfikacje w formie wyrobów, rosnącym zapotrzebowaniem z Japonii można tłumaczyć produkcję naczyń do sushi zapełniających półki sklepów zakładowych.

Jednocześnie producenci ceramiki starali się zainteresować wyrobami z kamionki polskich odbiorców. Włączanie ceramiki produkowanej w Bolesławcu do polskiej rzeczywistości społecznej, gospodarczej i kulturowej miało już miejsce w latach tużpowojennych (na wspomnianej już Wystawie Ziem Odzyskanych) i w czasach PRL-u (np. na Ogólnopolskiej Wysta-

17 https://regiony.rp.pl/archiwum/3690-z-baz-nato-do-ameryki-a-teraz-azja [dostęp: 05. 11.2019]; Violetta Waluk, Żony amerykańskich wojskowych $z$ baz w Niemczech przyjeżdżaja na zakupy do Bolesławca, 18 kwietnia 2004 (https://www.tygodnikprzeglad.pl/ceramika-podbijaswiat/ [dostęp: 05.11.2019]).

18 Reklama Ceramiki Artystycznej wyświetlana raz na kwartał skutkowała każdorazowo około 20 tys. zamówień (zob. https://www.tygodnikprzeglad.pl/ceramika-podbija-swiat/ [dostęp: 05.11.2019]).

${ }^{19}$ Ich zainteresowanie zdobywano na frankfurckich targach designu Ambiente.

20 Paweł Zwierz, Z baz NATO do Ameryki, a teraz Azja, wywiad, 24 sierpnia 2017 (https://re giony.rp.pl/archiwum/3690-z-baz-nato-do-ameryki-a-teraz-azja [dostęp: 05.11.2019]). 
wie Rzemiosł Artystycznych w Warszawie wyroby Zakładu Ceramicznego „Cer-Gor” z Nowogrodźca w 1973 roku zdobyły srebrny medal). Działania te były projektowane na szczeblu państwowym, w ramach odgórnych dyrektyw. Jednak szczególną popularność ceramika bolesławiecka — rozumiana przede wszystkim w pierwotnym znaczeniu jako zdobiona stempelkami bunzlauer keramik — zdobyła w Polsce w ostatnich dwóch dekadach.

W czasie okołotransformacyjnym zabiegi promocjne wynikały przede wszystkim $z$ interesów indywidualnych przedsiębiorców. Już nie imprezy propagandowe, ale komercyjne, wspierające gospodarkę wolnorynkową, narzucały im ton. Przykładem może być popularny w latach dziewięćdziesiątych XX wieku konkurs „Teraz Polska”, mający na celu wsparcie rodzimej przedsiębiorczości (w 1993 roku w tym konkursie została nagrodzona Ceramika Artystyczna Spółdzielni Rękodzieła Artystycznego).

Istotną rolę $\mathrm{w}$ promocji ceramiki odegrał również Bolesławiecki Kiermasz Ceramiczny, pierwszy raz zorganizowany z prywatnej inicjatywy w 1994 roku. W latach dziewięćdziesiątych kiermasz był „raczej skromny i biznesowo dość ubogi” ${ }^{21}$, co zmieniło się w 2000 roku, gdy ówczesne władze gminne dostrzegły jego potencjał jako narzędzia promocji miasta. Wówczas przemianowano go na „Bolesławieckie Święto Ceramiki” i wzbogacono o część artystyczną. Z biegiem lat bolesławieckie święto nabrało rozpędu, dodano pochód „Glinoludów” oraz „Zdobinek”, czyli uczestników pomalowanych gliną oraz ozdobionych charakterystyczną dekoracją stempelkową.

Stempelki zagarnęły przestrzeń miejską Bolesławca. Występują jako wielkoformatowe rzeźby, dekoracje na budynkach czy ciałach mieszkańców. Ceramika, przede wszystkim stempelki, stała się nieodłącznym elementem promocji gminy Bolesławiec, co więcej, także jednym z najważniejszych produktów krajowego brandingu — obok koronek koniakowskich i bursztynu jest podstawowym towarem eksportowym, utożsamianym z polskim dziedzictwem kulturowym ${ }^{22}$.

W największej mierze do wzmocnienia popularności ceramiki bolesławieckiej zarówno na polskim, jak i na międzynarodowym gruncie niewątpliwie przyczyniły się mechanizmy rynkowe. Jeszcze w latach dziewięć-

\footnotetext{
${ }^{21}$ Jak się kiermasz zmienit w święto... Historia powstania Bolesławieckiego Święta Ceramiki w Bolesławcu we wspomnieniach jego głównego pomystodawcy Stanisława Wizy, bobrzanie.pl, 20 września 2015 (https://bobrzanie.pl/2015/08/20/jak-sie-kiermasz-zamienil-w-swieto/?fbcld=IwAR 0CNWtkqPneC-yOUlambZiAvwXL3y1UK2KuZSLqtVecRYVJ7ciRpgPaUDc [dostęp: 05.11. 2019]).

22 Obecnie staraniem lokalnych władz oraz instytucji kultury został podjęty proces wpisania ceramiki na listę produktów regionalnych, w następnej kolejności - na polską listę niematerialnego dziedzictwa kulturowego oraz listę UNESCO.
} 
dziesiątych ubiegłego wieku $\mathrm{w}$ wyniku promocyjnych działań przedsiębiorstw ceramika zaczęła gościć na stołach polskich rodzin w popularnych serialach telewizyjnych, takich jak Klan czy $M$ jak mitość ${ }^{23}$. Polscy producenci sukcesywnie otwierali sklepy firmowe w całej Polsce: Wrocławiu, Warszawie, Łodzi, Lublinie, Gdańsku, Krakowie oraz innych większych miastach i ośrodkach turystycznych. Rozpoczęli również współpracę $\mathrm{z}$ projektantami $\mathrm{w}$ celu odświeżenia wzornictwa i dostosowania go do współczesnych wymagań. Równocześnie, co często jest podkreślane w wywiadach i reklamach ceramiki, producenci dbali o jakość wyrobów. Ich użyteczność (np. możliwość zmywania naczyń w zmywarce), na równi z wartością estetyczną, jest najczęściej wymieniana jako pożądana cecha ceramiki przez klientów na całym świecie.

\section{BOLESŁAWIECKA EKONOMIA (NIE)PAMIĘCI}

W przedstawionej historii bolesławieckiej ceramiki wyraźnie rysuje się dialektyka pamięci i zapomnienia, a więc znany i wielokrotnie analizowany przedmiot interdyscyplinarnych badań nad pamięcią, dynamicznie rozwijanych od ostatnich dekad XX wieku. Nasze rozważania dotyczą zjawiska analizowanego na poziomie społecznym, dlatego też sięgniemy po teorie opisujące zbiorowy, kulturowy wymiar pamiętania/zapominania: klasyczną pracę Maurice'a Halbwachsa (2008) dotyczącą pamięci zbiorowej oraz opartą na niej koncepcję niepamięci, opisaną przez Marię Hirszowicz oraz Elżbietę Neyman (2001). Halbwachs zakłada zależność pamięci indywidualnych od struktur i ram społecznych, dostrzega fakt jej konstruowania $\mathrm{w}$ interakcjach $\mathrm{z}$ innymi jednostkami, a także funkcję kształtowania oraz konsolidacji tożsamości grupowej i wynikający z niej selektywny charakter. Koncepcja niepamięci obejmuje to, co „znajduje się poza owym obszarem [pamięci zbiorowej - A.K., K.M.] — zarówno treści nie przyswojone, jak i te, które uległy eliminacji czy zapomnieniu" (Hirszowicz, Neyman 2001, s. 24), a także „społeczne luki” w kolektywnym pamiętaniu. Jej autorki wypunktowują ograniczenia propozycji teoretycznej Halbwachsa, wskazując, że społeczne interakcje wpływające na kształt pamięci rozgrywają się nie tylko pomiędzy jednostkami, ale również na poziomie międzyinstytucjonalnym (który kształtują doktryny religijne, mity i ideologie — dodajmy - propagowane między innymi w instytucjach muzealnych). Ponadto

23 Oglądalność M jak miłość w sezonie 2018/2019 sięgnęła 5,32 mln widzów (https://www. wirtualnemedia.pl/artykul/ogladalnosc-m-jak-milosc-serial-tvp2-znokautowala-konkurencje [dostęp: 05.11.2019]). 
na to, co zapamiętanie i zapomniane, wpływają środki i formy przekazu, a co szczególnie istotne, często „nie tyle uzgodnienia czy negocjacje, ile manipulacja [...] zablokowanie - tendencyjne - przekazu pewnych treści sprzecznych ze świadomością potoczną" (Hirszowicz, Neyman 2001, s. 28).

Napięcia między pamięcią a niepamięcią dotyczącą bolesławieckiej ceramiki pozostają w rozległej i złożonej relacji. Tak jak diagnozowały Hirszowicz i Neyman, są one ideologicznie motywowane (przykład działań propagandowych w PRL-u), ale również negocjowane i przekraczane (przypadek niemieckiej nostalgii i lokalnego zwrotu w pamięci polskiej historii). Prawdopodobnie mogą być również postrzegane jako mechanicznie reprodukowany efekt nie-wiedzy. Jednak dialektykę pamięci i nie-pamięci wpisaną w badany przykład dziedzictwa kulturowego warto wzmocnić analizą wartości z porządku ekonomicznej racjonalności.

Dotychczasowe analizy powiązań ekonomii z porządkiem kultury i sztuki zmierzały w kierunku akcentowania gospodarczego znaczenia kultury i były skupione na procesach związanych $z$ utowarowieniem dziedzictwa, a więc $z$ wyznaczeniem jego wartości pieniężnej. Krótko mówiąc, ujmowały dziedzictwo kulturowe i przemysły kreatywne jako generatora wartości ekonomicznych (Throsby 2010). Problematyzowały je opracowania skupione na negatywnych skutkach ekonomizacji kultury (Ziębińska-Witek 2015, s. 107-108; Ekonomia... 2010), które skupiały się między innymi na procesach komercjalizacji kultury oraz nastawieniu na rentowność wypracowywaną kosztem jakości. Fenomen ceramiki bolesławieckiej wskazuje jednak na jeszcze inny aspekt kulturowo-ekonomicznych zależności, pokazuje bowiem - co opisali Jean Comaroff i John L. Comaroff (2011) — jak neoliberalne mechanizmy generowania zysków doprowadziły do wytworzenia i ugruntowania pozycji ceramiki jako składowego elementu polskiego dziedzictwa kulturowego. W podsumowaniu chcemy więc zaproponować termin eko nomia (ni e) pa mięci, który obejmie rozmaite finansowo motywowane przekształcenia dziedzictwa kulturowego. Dotyczy on mechanizmów i zabiegów na pamięci lub jej braku, polegających na dodawaniu nowych treści i ujmowaniu tych niewygodnych. Opisuje bazowanie na niemieckiej nostalgii przez przedsiębiorstwo Heise, przystaje również do interpretacji serwisu „Niepodległa” wyprodukowanego przez Zakładu Cermamiczne „Bolesławiec” z okazji stulecia odzyskania przez Polskę niepodległości. Ten 22-elementowy komplet o florystycznym biało-czerwonym wzorze $\mathrm{w}$ cenie 5000 PLN buduje markę ceramiki bolesławieckiej jako synonimu polskości, operując przy tym na podatnej materii zapomnienia o przeszłości. Pojęcie ekonomii (nie)pa- 
mięci pokazuje siłę i żywotność kapitalizmu w procesach zawłaszczania historii i kultury, żerowania na aktualnych resentymentach i przekuwania ich w zysk. Pomaga ustalić, czy „w interesie” jest pamięć czy zapomnienie.

Bolesławiecka ceramika to dziedzictwo wielu dziedziców tworzone i tworzące się w tranzycie. Jej fenomen należy rozpisać na kilka równolegle występujących modalności. Jedną z narracji tworzy ruch od systemu komunistycznego do społeczeństwa (post)transformacyjnego, kapitalistycznego. Kolejną - niejednoznaczne przemieszczenia między utowarowieniem i użytecznością a obiegiem znaczeń i wartości charakteryzujących porządek dziedzictwa kulturowego. Na jego dzisiejszy kształt wpłynęły zarówno działania władzy w powojennej Polsce, a więc przekształcenia o charakterze systemowym, jak i sprawcze podmioty, takie jak prywatni przedsiębiorcy. Ponadto ten przykład (post)konfliktowej materialności tworzy intrygujący splot zarówno wolitywnej, jak i „mechanicznie” reprodukowanej pamięci z niepamięcią.

\section{BIBLIOGRAFIA}

Baniecki Adam, 2006, Ludność niemiecka w powiecie i mieście Bolesławiec w latach 1945-1949, w: Joanna Nowosielska-Sobel, Grzegorz Strauchold (red.), Trudne dziedzictwo. Tradycje dawnych i obecnych mieszkańców Dolnego Śląska, Atut-Wrocławskie Wydawnictwo Oświatowe, Wrocław, s. 40-59.

Bober-Tubaj Anna, Moniatowicz Janusz, 2014, Vademecum ceramiki bolesławieckiej / A Handbook of Boleslawiec Ceramics, Moniatowicz Foto Studio, Bolesławiec.

Comaroff Jean, Comaroff John L., 2011, Etniczność sp. z o.o., tłum. Wojciech Usakiewicz, Wydawnictwo Uniwersytetu Jagiellońskiego, Kraków.

Demshuk Andrew, 2012, Reinscribing Schlesien as Ślask: Memory and Mythology in a Postwar German-Polish Borderland, „History and Memory”, t. 24(1), s. 39-86.

Ekonomia..., 2010, Ekonomia kultury. Przewodnik Krytyki Politycznej, Wydawnictwo Krytyki Politycznej, Warszawa.

Górecki Bogdan, 2000, Bolesławiecka „Ceramika Artystyczna” 1950-2000, Spółdzielnia Rękodzieła Artystycznego „Ceramika Artystyczna”, Bolesławiec.

Halbwachs Maurice, 2008, Społeczne ramy pamięci, tłum. Marcin Król, Wydawnictwo Naukowe PWN, Warszawa.

Hirszowicz Maria, Neyman Elżbieta, 2001, Społeczne ramy niepamięci, „Kultura i Społeczeństwo", nr 3-4, s. 23-48.

Kordjak Joanna, 2016, Polska — krajfolkloru?, w: Joanna Kordjak (red.), Polska — kraj folkloru?, Zachęta Narodowa Galeria Sztuki, Warszawa, s. 11-24.

Korduba Piotr, 2013, Ludowość na sprzedaż. Towarzystwo Popierania Przemystu Ludowego, Cepelia, Instytut Wzornictwa Przemysłowego, Fundacja Bęc Zmiana, Warszawa.

Price Jon, 2005, Orphan Heritage: Issues in Managing the Heritage of the Great War in Northern France and Belgium, „Journal of Conflict Archaeology”, t. 1(1), s. 181-196. 
Rejwerska Barbara 2011, „Ocalić od zapomnienia”. O Tadeuszu Szafranie (1886-1955), „Rocznik Bolesławiecki”, t. 3, s. 8-11.

Schöne Sally, 2004, Zeichensaal, Labour und Werkstatt. Keramische Fachschulen in Deutschland zwischen Kaiserreich und Zweitem Weltkrieg, Verlag Janos Stenovics, Halle.

Sendyka Roma, 2018, Caduca, or es(cheat)ed heritage, „Trances” (http://www.traces.polimi.it/2018/07/26/caduca-or-escheated-heritage).

Siewior Kinga, 2019, Wielkie poruszenie. Pojattańskie narracje migracyjne $w$ kulturze polskiej, Instytut Badań Literackich PAN, Kraków.

Spindler Konrad, 2004, Bunzlau Keramik im Germanischen Nationalmuseum, Verlag des Germanischen Nationalmuseums, Nürnberg.

Starzewska Maria, Wolanin Teresa, 1995, Artystyczna kamionka bolesławiecka: katalog zbiorów Muzeum Narodowego we Wrocławiu i Muzeum Ceramiki w Bolesławcu, Muzeum Narodowe we Wrocławiu, Wrocław.

Throsby David, 2010, Ekonomia i kultura, tłum. Olga Siara, Narodowe Centrum Kultury, Warszawa.

Thum Gregor, 2007, Obce miasto. Wrocław 1945 i potem, „Via Nova”, Wrocław.

Zborowska Agata, 2019, Życie rzeczy w powojennej Polsce, Wydawnictwo Uniwersytetu Warszawskiego, Warszawa.

Ziębińska-Witek Anna, 2014, Muzea historyczne w XXI wieku. Transformacja czy trwanie, „Kultura Współczesna”, nr 4, s. 106-123.

Żak Katarzyna, 2007, Między tradycją a nowoczesnością. „Ceramika Artystyczna” Spółdzielnia Rękodzieła Artystycznego w Bolesławcu, Spółdzielnia Rękodzieła Artystycznego w Bolesławcu „Ceramika Artystyczna”, Bolesławiec.

\section{BOLESŁAWIEC POTTERY: HERITAGE IN TRANSIT}

Anna Kurpiel (Willy Brandt Center for German and European Studies University of Wrocław), Katarzyna Maniak (Jagiellonian University)

\section{Abstract}

This article analyses the phenomenon of stenciled ceramics from Bolesławiec, a city in Lower Silesia, which was annexed to Poland after the Second World War. On the basis of theories from the field of cultural heritage, memory studies, and economics, the authors trace the discrepancy between the modern view of these ceramics and their social and historical biography. As a result, they propose the use of two new terms, "heritage with multiple heirs" and the "economy of (non)memory," which would help people to understand this multidimensional phenomenon and would encompass the appropriation of cultural heritage, the negotiation of its meanings, and the role of cultural heritage in a neoliberal economy.

key words: cultural heritage, Lower Silesia, economy of (non)memory, heritage with multiple heirs, pottery from Bolesławiec, heritage in transit

słowa kluczowe: dziedzictwo kulturowe, Dolny Śląsk, ekonomia (nie)pamięci, dziedzictwo wielu dziedziców, ceramika bolesławiecka, dziedzictwo w tranzycie 